\title{
A new species of the genus Phaea Newman, 1840 (Coleoptera: Cerambycidae) from Argentina
}

\author{
Новый виА рода Phaea Newman, 1840 \\ (Coleoptera: Cerambycidae) из Аргентины
}

\begin{abstract}
D.G. Kasatkin
А.Г. Касаткин

Rostov Branch of FSI “VNIIKR", 20 th line, 43/16, Rostov-on-Don 344037 Russia. E-mail: dorcadion@yandex.ru Ростовский филиал ФГБУ «ВНИИКР», 20-я Аиния, 43/16, Ростов-на-Аону 344037 Россия
\end{abstract}

Key words: Coleoptera, Cerambycidae, Phaea, new species, Argentina, Salta.

Ключевые слова: Coleoptera, Cerambycidae, Phaea, новый виА, Аргентина, Сальта.

Abstract. A new species of the genus Phaea, Ph. tomkovichi sp. n., is described from Argentina. It is the first record of this genus for Argentina.

Резюме. Из Аргентины описывается новый виА рода Phaea - Phaea tomkovichi sp. n. (первое указание этого рода Аһя Аргентины).

The genus Phaea Newman, 1840 includes 58 species distributed mainly in the south of North America and in Central America [Chemsak, 1999; Bezark, Monne, 2013; Bezark, 2015]. At the moment, it is known only 6 species of this genus occurring in South America, Phaea andrewsi Chemsak, 1999, Ph. astatheoides Pascoe, 1866, Ph. brevicornis Chemsak, 1999, Ph. coccinea Bates, 1866, Ph. miniata Pascoe, 1858 and Ph. crocata Pascoe, 1866 (Chemsak, 1999). Species of the genus Phaea and any species of the tribe Tetraopini were unknown from Argentina until now. A new species of the genus from Argentina is described below.

A specimen was examined with Olympus SZ61 stereomicroscopes. The photographs were taken with Canon MP-E $65 \mathrm{~mm} / 2.8$ on bellows attached to Canon EOS 5D Mark III camera and Cognisys StackShot Macrorail. Partially focused images were stacked using Helicon Focus Pro v5.3.14 software.

\section{Phaea tomkovichi sp. n. (Color plate : 1-5)}

Material. Holotype, O̊: Argentina, Salta, 24.721 S / 6525.172 W 5-11.02.2013 (leg. K. Tomkovich) (in author's collection).

Description. Body length $8.5 \mathrm{~mm}$. Cuticles ruby-colored antennae, apex of mandibles, tibia and tarsi black. Head not large, moderately densely punctated, covered with sparse light recumbent hairs and separate erect black setae; gene slightly shorter than lower half of eye. Antennae reaching elytral apex, covered with very thin dark hairs and some erect long hairs on low side. Pronotum square, with large glabrous shining umbone on disk and pair not large lateral tubercles (Color plate 12:3). Base of pronotum with not deep constriction. Pronotal punctation fine, very sparse, almost invisible; with fine transverse rugosity at base; umbone with sparse large punctures bearing long erect hairs. Pronotum covered with light recumbent and more long erected hairs. Scutellum transverse, pentagonal. Elytra elongate, widest after middle, with widely rounded apices. Elytral punctation coarse, moderately dense, forming rows in basal half, irregular in apical half. Elytral pubescence consists of very thin (sculpture not hidden), light, recumbent hairs; surface of elytra additionally with long light erect hairs (denser at base of elytra) and short black setae (Color plate 12: 2). Each elytron with pair of black spots: first spot narrow and elongate from base to middle of elytron; second spot broad, occupies almost all apical third (Color plate 12:1). Pygidium triangular, rounded apically, with fine light hairs and coarser and longer dark setae. Apex of penis triangular, sharped; lateral lobes short, curved, with long hairs apically (Color plate 12: 4,5).

Female is unknown.

Differential diagnosis. The new species is most similar to Ph. coccinea and Ph. astatheoides and differs from $\mathrm{Ph}$. coccinea by completely black first antennomere and tibiae, black spots on elytra. Phaea astatheoides differs from the new species by elytral pattern, red tibiae and orange body. Phaea nigromaculata Bates, 1881 known only from the type specimens from Mexico also has 4 black spots on elytra. But it differs from Phaea tomkovichi sp. n. in robust body, not large and rounded elytral black spots and black pronotal umbone.

Etymology. The new species is named after Mr. Konstantin Tomkovich, who collected the holotype.

\section{Acknowledgements}

The author is grateful to Mr. K. Tomkovich (Moscow, Russia) for the provided material and Dr. Osvaldo R. Di Iorio (Buenos Aires, Argentina) for consultation.

\section{References}

Bezark L.G., Monne M.A. 2013. Checklist of the Oxypeltidae, Vesperidae, Disteniidae and Cerambycidae, (Coleoptera) of the Western Hemisphere. Rancho Dominguez: BioQuip Publications. 484 p.

Bezark L.G. 2015. A photographic catalog of the Cerambycidae of the world. New World Cerambycidae Catalog. Available at: https://apps2.cdfa. ca.gov/publicApps/plant/bycidDB/wdefault.asp (accessed 15 October 2015).

Chemsak J. 1999. Revision of the genus Phaea Newman (Coleoptera: Cerambycidae). Occasional Papers of the Consortium Coleopterorum. 3(1): 36-101. 



\section{3}
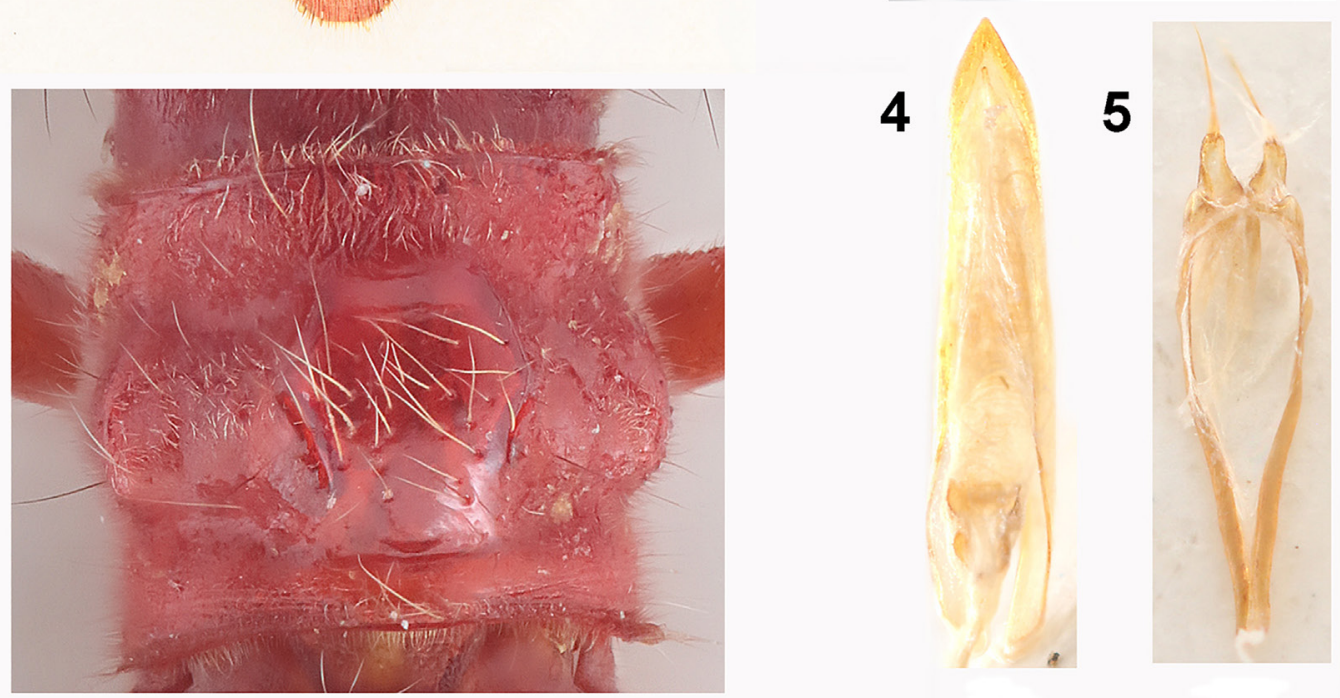

Figs 1-5. Phaea tomkovichi sp. n., holotype.

1 - general view, dorsally; 2 - general view, laterally; 3 - pronotum; 4-5 - male genitalia: 4 - penis, 5 - lateral lobes.

Рис. 1-5. Phaea tomkovichi sp. n., голотип.

1 - габитус, виА сверху; 2 - габитус, виА сбоку; 3 - переднеспинка; 4-5 - гениталии самца: 4 - пенис, 5 - парамеры. 